IRSH 59 (20I4), Special Issue, pp. I6I-I 83 doi:I0.I0I7/So0208590I4000388 (C) 2014 Internationaal Instituut voor Sociale Geschiedenis

\title{
The First Great Railway Strike: Rereading the Early Labour Movement in São Paulo*
}

\author{
G UILHERME GRAN D I \\ Department of Economics, University of São Paulo \\ Av. Prof. Luciano Gualberto 908, Cidade Universitária, \\ o5508-0I0 São Paulo-SP, Brazil \\ E-mail: ggrandi@usp.br
}

\begin{abstract}
AвSTRAct: By analysing the first great railway strike in São Paulo (Brazil), this article aims to understand the role of the Companhia Paulista railway workers' movement and its impact on labour relations in the São Paulo state. To that end, I have examined selected newspapers, the minutes of workers' meetings, police investigations into the strike, and the reports of the Companhia Paulista's directors. Differing from the views of other historians who have tended to see the 1906 railway strike as a relatively inconsequential conflict about wages, I interpret it both as rooted in deeper grievances about labour conditions and as a starting point for a period of heightened militancy and changing labour-management relations.
\end{abstract}

No written social history of the twentieth century is complete without an account of railway strikes. Because it has a strong impact, often longterm, strike activity in general offers a useful observation point for studying changes in labour relations. Although strikes are not the only form of labour conflict (others include sabotage, absenteeism, slowdowns, and boycotts), they remain more visible historically because they are usually better documented than other forms of labour protest. In the United States, for example, many scholars who have examined national strike data have been interested in the long-term relationship between strikes and the development of collective bargaining. ${ }^{\mathrm{I}}$ According

* This article is part of a postdoctoral research project developed at the Centre interuniversitaire de recherche en économie quantitative (CIREQ) at Université de Montréal (Québec, Canada) between September 20I2 and December 20I3. I want to thank Michael Huberman for his supervision and for his helpful suggestions on earlier versions of this article. I have also benefited from the comments of Jacques Rouillard at the Department of History, Université de Montréal. I owe special thanks to anonymous referees for their comments and suggestions. Responsibility for any error or omission is entirely mine.

I. Shelton Stromquist, A Generation of Boomers: The Pattern of Railroad Labor Conflict in Nineteenth-Century America (Urbana, IL, 1987), p. 25. 
to Gerald Friedman, strikes are the proving grounds of unions, which survive only when they can significantly increase the bargaining power of workers. ${ }^{2}$

In early twentieth-century São Paulo (Brazil) there was, as in many other places at the time, an inherent association between the militancy of urban workers, the organization of left-wing parties, and the union movement. The strategy of leftist uprisings was accomplished principally by means of strikes organized as mobilizations of workers and through rallies in public spaces. Most such upheavals had the support of the labour organizations that represented the oldest and most numerous types of industrial workers, such as railwaymen. The latter played an especially important role in the trajectory of the labour movement in São Paulo because they constituted one of the first categories to organize themselves against exploitation and to fight for better working conditions. It is for that reason that strike activity has been seen as such a key element in the progress of industrial workers. It is known that the railwaymen were not the only category of rank-and-file workers who went on strike, for at the turn of the century printers, shoemakers, glassmakers, bricklayers, textile workers, matchmakers, metalworkers, and port workers frequently did the same.

However, it appears that railway strikes were more visible than other labour disputes because they could unify a larger number of employees. Moreover, railway strikes tended to be more disruptive to other economic activities and the repercussions were always greater for society than the effects of strikes in other industries. The interruption of rail traffic and its consequences for the trade and manufacturing sectors made rail strikes particularly serious and commanded extraordinary attention from the state and public, because solutions needed to be found quickly. Railway workers, as well as other kinds of skilled workers, had considerable bargaining power, which enabled them to structure their unions, and they had great influence upon labour movements around the world. All in all, they were one of the few groups who could embody a broadly based labour movement in São Paulo state during the first few decades of the twentieth century.

There is an extensive literature on Brazil's general railway history, ${ }^{3}$ but little exists about the formation of the railway working class specifically

2. Gerald Friedman, "Strike Success and Union Ideology: The United States and France, I880-1914", Journal of Economic History, 48 (1988), pp. I-25, I-3.

3. The most important studies on Brazilian railways are: Julian S. Duncan, Public and Private Operation of Railways in Brazil (New York, 1932); Odilon N. de Matos, Café e ferrovias: a evolução ferroviária de São Paulo e o desenvolvimento da cultura cafeeira (São Paulo, 1974); Flávio Saes, As ferrovias de São Paulo 1870-1940: expansão e declínio do transporte ferroviário em São Paulo (São Paulo, I98 I); Liliane Segnini, Ferrovias e ferroviários: uma contribuição para $a$ análise do poder disciplinar na empresa (São Paulo, I982); Colin M. Lewis, Public Policy and 
and the conflicts involving the railway capital, the early labour movement, and the state's repressive apparatus. The main reason for this lack might be the great difficulty encountered in tracking down the political actions of railway workers in the sources. The railway sector represented an area of early government activity in Brazil, with the financing of construction, promotion of incorporation, and the regulation of operations being only the most prominent aspects of state intervention in the sector from the second half of the nineteenth century onwards. Nonetheless, most of the Brazilian historiography on business enterprises has not focused on the analysis of railway labour-management relations. This article approaches that relationship, which, as a by-product of the state's conflict with labour, eventually brought about a new framework for labour-management cooperation in São Paulo state.

The history of Brazil shows a growing trend towards increased state control over labour relations as working conditions and wage levels were systematically constrained by rules, regulations, and economic policy decisions, all established by a number of government agencies. Furthermore, legislation and the state's repressive power both interfered with and obstructed workers' actions. With the founding of the Brazilian Workers' Confederation (Confederação Operária Brasileira) through the first Brazilian Labour Congress, which took place at Centro Gallego in Rio de Janeiro on I 5-20 April 1906, several union representatives tried to organize the labour movement nationally. ${ }^{4}$ By organizing meetings and editing newspapers, the partisans of "revolutionary unionism" began to foster people's awareness of the need for better living conditions and basic social entitlements. ${ }^{5}$

Scholars who have studied the history of the Brazilian labour movement have tended to use newspapers as a primary source to investigate the labour movement's path. ${ }^{6}$ Dulce Leme's thesis on the first great railway

Private Initiative: Railway Building in São Paulo 1860-1889 (London, 1991); William R. Summerhill, Order against Progress: Government, Foreign Investment, and Railroads in Brazil, I854-I9I3 (Stanford, CA, 2003); Maria L. Lamounier, Ferrovias e mercado de trabalho no Brasil do século XIX (São Paulo, 2012).

4. The set of resolutions of the First Brazilian Labour Congress are available in Paulo S. Pinheiro and Michael M. Hall (eds), A Classe Operária no Brasil: documentos (I889 a I930), vol. I, O Movimento Operário (São Paulo, 1979), pp. 46-58.

5. A good interpretation of the ideological segmentation and attitudes that characterized early Brazilian unionism can be found in Cláudio Batalha, "Syndicalisme révolutionnaire et syndicalisme réformiste. Les modèles européens dans le mouvement ouvrier brésilien (I906-1920)", in Tanja Régin and Serge Wolikow (eds), A l'épreuve de l'international (Paris, 2002), pp. I 5-26. On the socialist movement among Italian immigrant workers in São Paulo, see Luigi Biondi, Classe e nação: trabalhadores e socialistas italianos em São Paulo, I890-I920 (Campinas, 20II). 6. Sheldon L. Maram, "Labor and the Left in Brazil, I890-1921: A Movement Aborted", Hispanic American Historical Review, 57 (1977), pp. 254-272; idem, Anarquistas, imigrantes e o 
strike in São Paulo, which was organized by workers at the Companhia Paulista de Estradas de Ferro (CPEF) in 1906, is still a main reference for the study of this conflict. ${ }^{7}$ Even though many researchers have commented on this railway strike, most of them offer little more than relatively general observations of it. By analysing the great railway strike of 1906, the objective of this article is to understand the role of the CPEF railway workers' movement during and immediately after the strike. For this purpose, I have examined selected newspapers, the minutes of workers' meetings, police investigations into the causes and consequences of the strike, and the reports of the CPEF's directors. I intend to answer the following questions: how did the first great railway strike begin; what were its causes; what forms of organization and action emerged during the strike; and what were the consequences?

The railway strike of 1906 at the CPEF, the most important privately owned railway company in São Paulo at the beginning of the twentieth century, has previously been interpreted mainly as conflict about wages. ${ }^{8}$ As the study by Leme and my own research, however, make clear, it was a personal disagreement between a station chief and one of his subordinates that sparked the walkout. Of course, there were also economic complaints among the workers' demands during the entire duration of the strike, but the kernel of it concerned agitation for the dismissal of certain ruthless managers. The strikers demanded an end to disrespect, threats, humiliation, persecution, and all the arbitrariness that the railway management was practising at that time. If we consider the list of all the grievances expressed by the workers, they were challenging the abuse of the power of patronage, their own harsh working conditions, and oppressive and unfair work rules. In addition, the CPEF's authoritarianism was tempered by a remarkable paternalism as a means of controlling the labour organizations and avoiding the diffusion of militant class-consciousness among workers.

This article is organized as follows: in the first section, I briefly review some of the literature on railway and immigration in São Paulo and discuss the movement that led to the mobilization of labour and, more specifically, of CPEF railway workers. In this initial phase, the labour press and the formation of the first labour organizations had an undeniable importance in

movimento operário brasileiro, I890-1920 (Rio de Janeiro, I979); Boris Fausto, Trabalho urbano e conflito social, I890-I920 (São Paulo, I986); Joel Wolfe, "Anarchist Ideology, Worker Practice: The 1917 General Strike and the Formation of São Paulo's Working Class", Hispanic American Historical Review, 7I (1991), pp. 809-846.

7. Dulce Leme, “Hoje há ensaio': A greve dos ferroviários da Cia. Paulista, i906” (M.A., University of Campinas, 1984).

8. Fausto, Trabalho urbano e conflito social; Robert H. Mattoon, "The Companhia Paulista de Estradas de Ferro, I868-1900: A Local Railway Enterprise in São Paulo, Brazil” (Ph.D., Yale University, 1971). 
the process of developing political awareness among railway workers. The second section gives some details of the railway strike of 1906, which resulted from a conflict in the CPEF's labour-management relations. The third section discusses the rise of working-class solidarity in support of the railway strikers and of the outcomes of the strike. The last section summarizes my most significant findings and their implications for the historiographical knowledge about the great railway strike of 1906, in particular, and the labour movement in São Paulo, in general.

\section{RAILWAY EXPANSION, IMMIGRATION, AND THE RISE OF THE LABOUR MOVEMENT}

The establishment of railway corporations led to significant changes in labour relations in Brazil. The prohibition on the use of slave labour, the need for a variety of skilled and semiskilled workers, and the presence of a great many immigrants in the service of the railway were all part of the general transition from slave labour to free wage labour. Furthermore, the expansion of the national rail network was related to cycles of growth and downturns in the Brazilian economy and to the seasonal rhythms of a transport system dependent on export-oriented agriculture. José Cechin argues that in Brazil the trains reduced transport costs, expanded markets, and subjected all production units located within their reach to the same inexorable dynamic of competition. ${ }^{9}$

The demand for railway building increased considerably from the I 860 s. A huge number of kilometres of new railway were being built and those already in operation required more and more workers for their maintenance and operation. Moreover, due to labour shortages, not only construction gangs but also workers were recruited by subcontractors, and this consequently pushed wages higher. Urban centres, including Rio de Janeiro, the national capital of the time, were not yet the labour reservoirs they would become in the 1890 s, and the agriculture sector tended to absorb almost all existing free labour. Finding men in the capital and in São Paulo - the hubs of industry - to wield picks and shovels was not easy, and labour shortages was a difficult and persistent problem in railway building. Therefore, railway contractors received contingents of both slaves and free labourers. The latter was nurtured mainly by internal and external migration. ${ }^{\circ}$

The foreign-born population made up a large proportion of São Paulo's

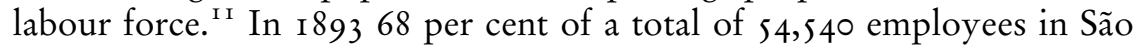

9. José Cechin, “A construção e operação das ferrovias no Brasil do século XIX” (M.A., University of Campinas, I978), pp. I $3^{-1} 4$.

ı०. Mattoon, "The Companhia Paulista".

I I. Warren Dean, The Industrialization of São Paulo, I880-1940 (Austin, TX, 1969). 
Paulo's various industries were foreign. Considering the manufacturing, commerce, and transport sectors, they made up almost 80 per cent of the labour force. ${ }^{\mathrm{I} 2}$ Between $\mathrm{I} 870$ and 1920 , it is estimated that about 2.5 million immigrants arrived in São Paulo, mostly to work on coffee plantations. Initially, the farmers (or São Paulo's ruling class) had no interest in establishing colonial settlements but only in replacing slave labour with cheap labour. ${ }^{3}$ In sum, Brazil was fourth among the New World countries in terms of the number of foreign migrants received from I 870 to I9I4.

The expansion of the rail network was essential in contributing to the improvement of the mobility of the incoming workers and to the proliferation of the coffee crop throughout São Paulo state. Indeed, railway building and operations were the principal economic activities listed in the first Brazilian industrial census, and by the I 900 s the railway sector's share of the gross value of industrial production in São Paulo was 7I per cent (equivalent to 84,000 contos de réis), ${ }^{\mathrm{I}}{ }^{4}$ and it employed I $8,50 \mathrm{I}$ people out of an industrial workforce of 25,000. Additionally, railway capital increased from 96,000 contos de réis in I885 to 360,000 contos de réis in I910, while investment in the São Paulo textile industry - the second most significant sector - was only 46,650 contos de réis in the same year. ${ }^{15}$

When examining the expansion of the Brazilian rail network as a whole, William Summerhill observed: "The largest percentage increase on an annual basis came in the first decade of operation [...]. In contrast to the large percentage increases in the I860s, the early twentieth century witnessed the largest absolute increases in track." "T Table I confirms that the first decade of the twentieth century saw the greatest increase in length of railway track, but the most significant increase in São Paulo occurred during the first phase of railway development in the state, during the i 870 s. Overall, the national rail network increased 86.3 per cent between 1900 and I920: from I 5,3 I 6 kilometres to 28,535 kilometres.

The building of the railways created enormous pressure on a labour supply that was otherwise largely employed in agriculture. At the same time, the demand for "hands for farming" received a great boost with the creation of the Associação Auxiliadora da Colonização e Imigração by the

I2. Fausto, Trabalho urbano e conflito social.

13. Zuleika Alvin, "O Brasil italiano (1880-1920)", in Boris Fausto (ed.), Fazer a América: a imigração em massa na América Latina (São Paulo, 2000), pp. 383-418.

I4. Until 1942, the baseline Brazilian currency unit was the mil-réis. One mil-réis was expressed numerically as I \$000 réis. A larger unit was the conto de réis. One thousand milréis was the equivalent of one conto de réis and was written as $\mathrm{i}: 000 \$ 000$. Thus, 84,000 contos de réis would be written as $84: 000 \$ 000$.

I 5. Wilson Cano, Raizes da concentração industrial em São Paulo (São Paulo, I990), pp. 52-53. I6. Summerhill, Order against Progress, p. 55. 
Table I. Railway track in service in Brazil and São Paulo (kilometres)

\begin{tabular}{lccccc}
\hline Year & $\begin{array}{c}\text { Brazil } \\
(1)\end{array}$ & $\begin{array}{c}\text { Kilometres added } \\
\text { in given year }\end{array}$ & $\begin{array}{c}\text { Percentage increase } \\
\text { in given year }\end{array}$ & $\begin{array}{c}\text { São Paulo } \\
(2)\end{array}$ & $\begin{array}{c}(2) /(1) \\
(\%)\end{array}$ \\
\hline 1855 & 15 & 0 & 0 & - & - \\
1860 & 223 & 113 & 51 & - & - \\
1865 & 498 & 24 & 5 & - & - \\
1870 & 744 & 7 & 1 & 139 & 19 \\
1875 & 1,801 & 517 & 29 & 655 & 36 \\
1880 & 3,398 & 457 & 13 & 1,212 & 36 \\
1885 & 6,930 & 628 & 9 & 1,640 & 24 \\
1890 & 9,973 & 390 & 4 & 2,425 & 24 \\
1895 & 12,967 & 707 & 5 & 2,962 & 23 \\
1900 & 15,316 & 401 & 3 & 3,373 & 22 \\
1905 & 16,781 & 475 & 3 & 3,842 & 23 \\
1910 & 21,326 & 2,085 & 10 & 5,204 & 24 \\
\hline
\end{tabular}

Sources and notes: Growth of railway track in Brazil from Summerhill, Order against Progress; São Paulo’s railway track from Saes, As ferrovias de São Paulo. All distances and all percentages rounded to the nearest whole number.

export-oriented bourgeoisie in I87r. Subsequently, in I886, the settlement programme was further expanded through the establishment of the Sociedade Promotora da Imigração by Martinho Prado, Nicolau de Sousa Queiróz, and Rafael de Barros (three members of the export-oriented bourgeoisie) subsidizing the arrival of foreign workers in São Paulo.

Despite the great encouragement of foreign labour by coffee growers, there were plenty of conflicts involving employers (the export oligarchs and the new industrial bourgeoisie) and employees (foreign and native workers), both on farms and in firms. The first workers in São Paulo and Rio de Janeiro at the beginning of the twentieth century had limited experience of factory life, since a significant portion of the labour force comprised immigrants from the rural areas of southern Europe. Despite their unfamiliarity with industry, however, most of them had some previous experience with political mobilization and many of the workers seemed familiar with the repertoire of labour protests, parties, and unions in Europe.

There is no doubt that European migrants took a prominent place in the early labour movement in São Paulo, when urban workers began to acquire their own working-class consciousness. ${ }^{17}$ After Brazil abolished slave labour in 1888 as the last country in the Americas, the protection of

17. It should be mentioned, however, that some historians have challenged the assumption of the essential role of European migrant workers in the rise of organized labour in São Paulo. See, for instance, Michael M. Hall, "Immigration and the Early São Paulo Working Class", Jabrbuch für Geschichte von Staat, Wirtschaft and Gesellschaft Lateinamerikas, I 2 (1975), pp. 393-407. 
industrial workers became a key aim for social activists worldwide. ${ }^{18}$ In São Paulo, the labour press reveals that workers were heavily influenced by the European revolutionary labour movement, mediated into Brazilian context especially by Italian immigrants. Also, many railway workers had originally come from Italy, Portugal, or Spain. Labour conflicts became more frequent as the labour movement began to take a more definite shape. Between 1900 and I903, São Paulo society was shaken by many disputes, such as the walkouts in the weaving industry (Anhaia e Penteado factory) and in the glass industry (Santa Maria factory). ${ }^{19}$ About the latter, it is crucial to note that the factory's owner was Antonio Prado, the most important traditional coffee fortune holder in São Paulo and the chairman of the CPEF.

During the first decade of the twentieth century, 94.6 per cent of all newcomers to São Paulo state came from outside the country (dropping only slightly to 90.6 per cent in the decade 1910-1920), data which give credence to the view that there was a correlation between the increase in worker upheavals, which grew from I90I to I920, and the high influx of immigrants. ${ }^{20}$ The first attempts of railway workers to organize themselves professionally originated in the late nineteenth and early twentieth centuries, when worker leagues began to emerge as predecessors of the modern labour union. Railwaymen, together with printers, shoemakers, tailors, milliners, and weavers, were the pioneers in founding such leagues, which organized the first wave of strikes in São Paulo demanding improved working conditions and some basic level of insurance.

By the turn of the century, labour leaders were meeting under the auspices of the Brazilian Workers' Confederation, but conflicts between adherents of anarchist activism and socialist sentiment splintered the movement, with the result that workers' representatives began to meet along sector or industrial lines. Although groups were evolving on the

I8. Michael Huberman, Odd Couple: International Trade and Labor Standards in History (New Haven, CT, 20I 2), p. 72. However, the divergence in the labour histories of Old and New World countries is remarkable and has persisted into the twenty-first century. In Europe, unions and their representatives succeeded in improving working conditions, embodied in new labour laws, while in the New World labour and social reformers had less success in pushing forward the social agenda. According to Huberman, "the asymmetry between Old and New Worlds' attitudes toward immigration was telling. In the New World, the cry for tighter immigration controls supplanted appeals for labor regulation and social insurance. In the relatively open and more inclusive Old World, the call for better labor regulations was louder than the demand for restrictions on foreign labor. The net result was that population movements within Europe strengthened the continent's attachment to the labor compact, while elsewhere immigration weakened it"; ibid., pp. 76-77.

19. For more details see Alceste De Ambris, "Il movimento operaio nello Stato di São Paulo", in Vitaliano Rotellini, Il Brasile e gli Italiani. Pubblicazione del 'Fanfulla' (Florence, I 906).

20. Cheywa R. Spindel, Homens e máquinas na transição de uma economia cafeeira (Rio de Janeiro, I979), p. I29. 
same revolutionary political platform, the imagined brotherhood they proposed failed to mask underlying cleavages. According to some historians, one of the causes that limited the development of a broad and effective labour movement was the ideological, social, and gender differences between the leadership and São Paulo's working class. Sheldon Maram, Boris Fausto, and John Dulles all stressed the ambivalent relationship between labour leaders and rank-and-file militancy. ${ }^{21}$ Concerning the anarchist-oriented labour activism that was a noticeable mark of the Brazilian Workers' Confederation, Joel Wolfe adds: “Brazil's early anarchist movement owed more to the antistate politics of disaffected Republicans than it did to working-class organizing." ${ }^{22}$

Others have asserted, more strongly, that the "ethnic and national" issue should be considered the "primary cause" of the disorganization and ineffectiveness of São Paulo's labour movement. ${ }^{23}$ Throughout the New World, the complaint was that foreign workers diluted labour organization, complicating negotiations of social entitlements, while the high geographical mobility of workers seemed to be another serious challenge to organized labour. ${ }^{24}$ The constant lack of stability among foreign workers gave them little opportunity to create ties of solidarity with their fellow workers, and conflicts between immigrant and native groups, as well as between Italian and Portuguese migrants jeopardized the outcomes of collective bargaining. ${ }^{25}$ Militant labour's attempts to build links with rural workers and small peasants were equally unsuccessful. The very first labour uprisings were the result of a critical situation that involved a high level of labour exploitation and adverse working conditions. On the more political plane, which developed only subsequently, the labour movement in Brazil, similar to other New World countries, began as a popular struggle for democracy. Battle was joined over the right of every individual to a voice in matters that affected him

21. Maram, "Labor and the Left in Brazil"; Fausto, Trabalho urbano e conflito social; John Dulles, Anarchists and Communists in Brazil, 1900-1935 (Austin, TX, 1973).

22. Joel Wolfe, Working Women, Working Men: São Paulo and the Rise of Brazil's Industrial Working Class, 1900-1955 (Durham, NC, I993), p. I I.

23. Hall, "Immigration and the Early São Paulo Working Class", p. 398.

24. In a comparison with European countries, Alberto Alesina and Edward Glaeser present familiar arguments to explain why the United States could not have established a US Communist Party: "Successive waves of immigration to the United States of ethnically diverse members of the working class created cleavages across racial and ethnic lines, which 'confused' and diluted the classic class line of Marxism [...]. These immigrants may have had a propensity to find an individual (or individualistic) solution to adversity rather than fomenting a social revolution at home"; Alberto Alesina and Edward L. Glaeser, Fighting Poverty in the US and Europe: A World of Difference (Oxford, 2004), p. 9.

25. Kim D. Butler, Freedoms Given, Freedoms Won: Afro-Brazilian in Post-Abolition São Paulo and Salvador (New Brunswick, NJ, 1998). 
(though seldom her). At the same time, the very ideal of democracy was lost in the separate labour organizations: it was turned into a bargaining chip in the disputes between the workers' leaders and their entrepreneurial opponents gaining material concessions in return for curbing rank-and-file activism.

The labour experience in Brazil had much in common with that in other regions of recent settlement in the Americas. The "soujourner" phenomenon and ethnicity, to take one example, both had a considerable impact on labour organization in the province of Quebec in Canada. Anglo-Celtic, French-Canadian, and Jewish workers predominated in different trade unions, indicating that the ethnic and religious division within the Quebec working class was as commonplace as it was entrenched organizationally. Militancy was further restrained by the inability of workers to put forward a persuasive and unified voice at the political level. As with their counterparts in São Paulo, different political ideologies tended, in a complicated amalgam, to be associated with certain ethnic identities. While French-Canadian workers had a tradition of labourism, i.e. advocating a strict separation of unionism and politics, most socialists were Anglo-Celtic and European migrants. ${ }^{26}$ As with the workers in São Paulo, in the dispute between ideals and interests the labourists seem to have had the upper hand, as strongly suggested by the fact that most strikes were conducted by the best-paid workers in order to advance the interests of their own particular craft. The end result was a growing divide between skilled and unskilled workers because the lack of solidarity meant that the bargaining leverage enjoyed by select groups of workers was prevented from being disseminated throughout the whole working class.

The first unions in São Paulo were organized by certain craft workers along narrow lines that excluded ordinary factory workers and rural workers. The unwillingness of entrepreneurs to recognize the autonomy of workers' groups in pursuit of their union organization was one more obstacle faced by the labour leadership - and a daunting one. The new class of industrialists maintained the same approach as the old planters, who had been accustomed to the slave system for so long. That fact, associated with the almost total lack of labour laws, created the conditions for employers to act ruthlessly; and to be sure, during the late nineteenth and early twentieth centuries Brazilian railway management was made up of individuals who saw no benefit in good labour relations. There is

26. Geoffrey Ewen, “Quebec: Class and Ethnicity”, in Craig Heron (ed.), The Workers' Revolt in Canada, 19I7-I925 (Toronto, I998), pp. 87-I43. Jean Hamelin, Paul Larocque, and Jacques Rouillard have provided a benchmark compilation of Quebec strike data, entitled Répertoire des grèves dans la province de Québec an XIXe siècle (Montreal, 1970). Of the total of 227 strikes recorded by various newspapers during the period I 843 to I900, 30 (I 3.2 per cent) were related to labour disputes in railway building, maintenance, or operating. 
certainly much evidence that labour-related matters were of little concern to employers. Robert Mattoon comments on the case of the CPEF management stating that "the almost total lack of descriptive information about working conditions suggests that the care and well-being of lowranking employees was less than a constant preoccupation of Company directors". ${ }^{27}$

Faced by growing labour pressures, the CPEF responded in a predictably discreet manner designed to ensure orderly business operations. The company built houses and schools near its workshops in the cities of Jundiai, Campinas, and Rio Claro in order to meet the need to expand its labour force, and with the same purpose it offered training programmes for new employees. The average number of trainees per month grew from thirty-eight to sixty-seven between I 896 and I90I, and, according to the CPEF's chief of workshops, the railway workforce increased by ro per cent in I90I due to the successful expansion of the company's training programme ${ }^{28}$ At the same time, it was increasingly difficult for the CPEF to maintain its accustomed paternalistic control, even though it took the initiative in forming a cooperative association of company employees. The Associação Beneficente e Cooperativa dos Empregados da Companhia Paulista (Paulista Benevolent Society) was a typical mutual aid society like others that were emerging in Brazil in those early days of organized labour. Their aims were to provide financial and medical support to the families of workers disabled or killed at work, as well as legal assistance, schools, hospitals, and cooperative stores for working families. ${ }^{29}$ In Brazil as a whole, paternalistic control appears to be associated with the rise of early mass-production industries. As with the seniority rules observed in other countries, Brazilian paternalistic management was conducted by foremen as a means of bolstering loyalty while preserving the benefits of a trained workforce.

Initially in São Paulo, the main complaints from railway workers involved the matter of seniority, the laying off of men for belonging to a labour organization, the reinstatement of men following a stoppage, the continuation of wage payments, injuries on the job, and work rules in general. Railway management put a lot of pressure on workers, which sometimes led to the erosion of solidarity and even to divisions between workers. Employees were also highly vulnerable to dismissal for insubordination. Many of them were forced into supporting their foreman's managerial criteria against other workers associated with a radical labour organization. Labour conflicts occurred when some groups

27. Mattoon, "The Companhia Paulista", p. I99.

28. Companhia Paulista de Estradas de Ferro, Relatório da Diretoria da Companhia Paulista de Vias Férreas e Fluviais apresentado à Assembleia Geral dos Acionistas (São Paulo, I902), p. 296. 29. Mattoon, "The Companhia Paulista", p. 203. 


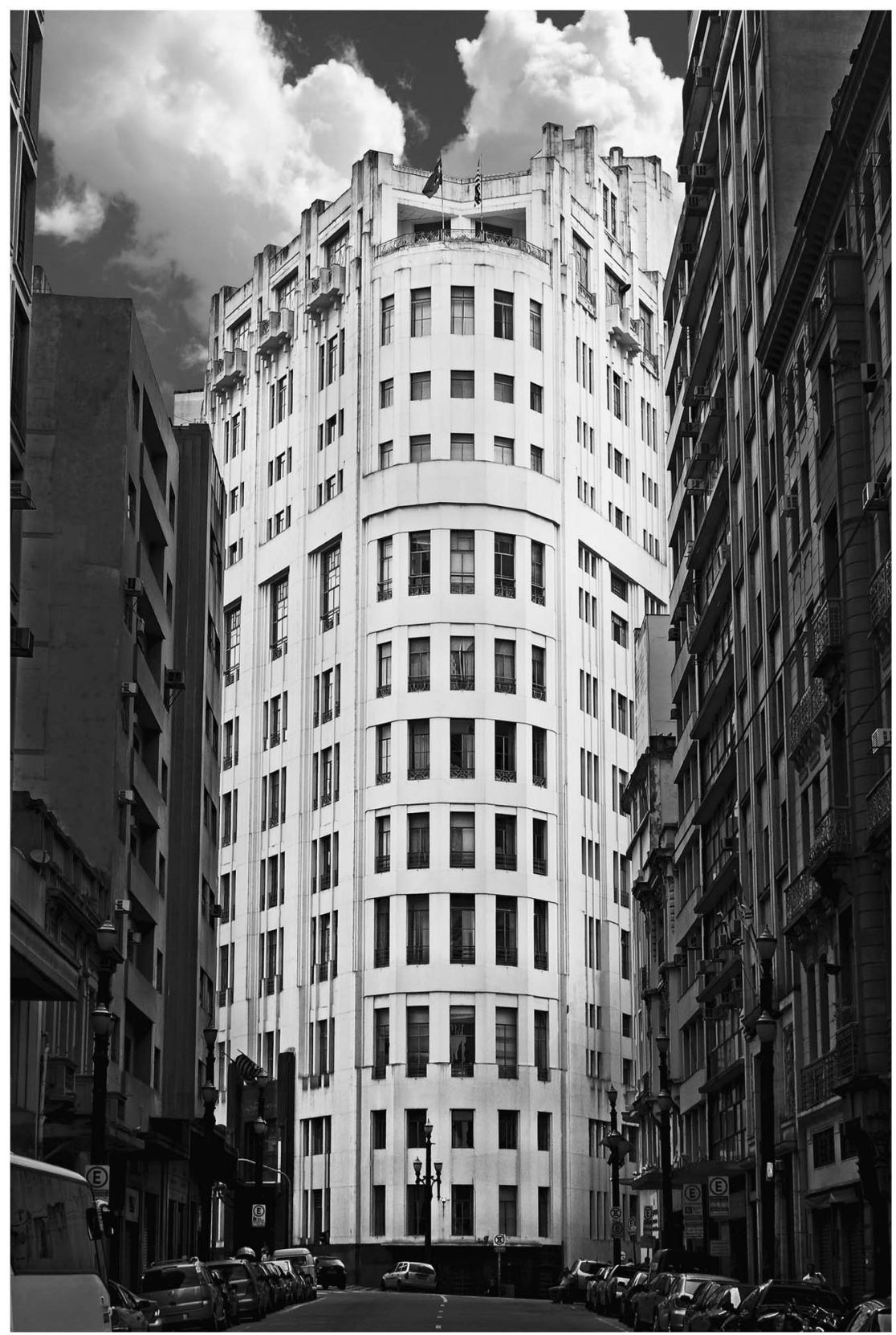

Figure I. The CPEF central office: a representation of the power of railway capital. The building, which is one of the first examples of art deco style in Sao Paulo city, completed construction in the I930s. Today it houses the headquarters of the Secretary of Public Security of Sao Paulo state. Photograph: Juan Esteves. Used with permission. 
of workers had become sufficiently familiarized with work routines to be able to organize and pursue common goals. In that regard, as mentioned above, the most important step towards the organization of labour on the São Paulo railways was the formation of regional worker leagues, which mobilized the railway working class and encouraged bargaining practices. Despite the high levels of initial investment in the roadbed and capital equipment all railways require, labour was an increasingly important factor in railway output.

The distribution of each grade of CPEF workers is presented in Table 2. Railwaymen were a very diverse occupational group. The variety of skills needed for railway work was remarkable, and no other industry can be found in early twentieth-century Brazil with such diversity of labour tasks. The figures in Table 2 show that while the CPEF white-collar occupations (general officers and office clerks) saw the largest relative increase in their numbers (68 per cent) between I90I and I9I4, the number of jobs related to the actual movement of traffic (including work in and around stations in freight and passengers) provided the largest increase in absolute terms ( 1,485 new station men and shop men). Furthermore, railwaymen worked under constant disciplinary threat and always faced the risk of being laid off, both by foremen and chief engineers. Despite the potential for occupational advancement, employment conditions may be defined as precarious and unstable, because railway workers had to deal with a working environment where dismissal for technical or disciplinary reasons seemed to be the norm. As a consequence of those hazards, employment insecurity was a constant concern in São Paulo's railway labour market at the turn of the century.

\section{THE OUTBREAK OF THE RAILWAY STRIKE OF 1906}

The most probable causes of the first great railway strike in São Paulo were concerns about job security and working conditions, seemingly common in all countries during the early stages of industrialization. Edited for the most part by immigrants, Brazilian workers' newspapers often complained about filthy working environments. Thus, poverty, food shortages, exploitation, low wages, and long hours of work were the main subjects discussed, and, to sum up, the social role of newspaper editing was to raise working-class consciousness and to contribute to the struggle for better working regulations and social entitlements. Labour disputes were not seen as something deserving regulation in terms of effective bargaining mechanisms because they were simply forbidden by the Brazilian state. As a result, the first strikes were illegal and violently repressed by the police.

Dissatisfaction among the CPEF's workers increased considerably from October 1905, when the company forced its staff to take three workdays off per month, citing cost-cutting as the reason. The company's work 
Table 2. CPEF railway workers by grade

\begin{tabular}{|c|c|c|c|c|c|c|c|c|c|c|}
\hline \multirow[b]{2}{*}{ Category } & \multicolumn{2}{|c|}{1901} & \multicolumn{2}{|c|}{1909} & \multicolumn{2}{|c|}{1911} & \multicolumn{2}{|c|}{1912} & \multicolumn{2}{|c|}{1914} \\
\hline & Number & Percentage & Number & Percentage & Number & Percentage & Number & Percentage & Number & Percentage \\
\hline White-collar & 100 & 2.0 & 129 & 2.3 & 137 & 3.0 & 159 & 3.3 & 168 & 3.3 \\
\hline Station men & 1,052 & 20.6 & 1,214 & $21.9\}$ & 1,828 & 40.8 & 1,944 & 40.2 & 1,947 & 38.1 \\
\hline Trainmen & 284 & 5.6 & 342 & $6.2\}$ & & & & & & \\
\hline Engineers & 7 & 0.1 & 14 & 0.3 & - & - & - & - & - & - \\
\hline Conductors & 86 & 1.7 & 104 & 1.9 & - & - & - & - & - & - \\
\hline Firemen & 90 & 1.8 & 103 & 1.9 & - & - & - & - & - & - \\
\hline Others & 101 & 2.0 & 121 & 2.2 & - & - & - & - & - & - \\
\hline Trackmen & 839 & 16.4 & 1,149 & 20.7 & 1,196 & 26.7 & 1,229 & 25.4 & 1,136 & 22.2 \\
\hline Shopmen & 1,274 & 24.9 & 1,188 & 21.4 & 1,320 & 29.5 & 1,504 & 31.1 & 1,864 & 36.4 \\
\hline Machinists & 35 & 0.7 & 30 & 0.5 & - & - & - & - & - & - \\
\hline Carpenters & 87 & 1.7 & 85 & 1.5 & - & - & - & - & - & - \\
\hline Others & 1,152 & 22.6 & 1,073 & 19.3 & - & - & - & - & - & - \\
\hline Total & 5,107 & 100 & 5,552 & 100 & 4,481 & 100 & 4,836 & 100 & 5,115 & 100 \\
\hline
\end{tabular}

Sources and notes: Companhia Paulista de Estradas de Ferro, Relatório da Diretoria da Companhia Paulista de Vias Férreas e Fluviais apresentado à Assembleia Geral dos Acionistas (São Paulo, I902), 30 June 1902, and the corresponding reports for 30 June 1910, 30 June I9I2, 30 June I9I 3 and 30 June I9Is. Unfortunately, from the second decade of the twentieth century I could find no further distinction in railway worker categories in the CPEF directors' reports, because the reports began listing only aggregate data on the workforce. Thus, the reports' denomination "Linhas e Edificios" corresponds to the occupation of trackmen in the table and "Trafego e Telegrapho" is represented by the station men and trainmen grades jointly. 
Table 3. Employees in three railway companies of São Paulo

\begin{tabular}{|c|c|c|c|c|c|c|}
\hline \multicolumn{4}{|c|}{$\begin{array}{l}\text { Average no. of employees per } \\
\text { kilometre of track }\end{array}$} & \multicolumn{3}{|c|}{$\begin{array}{l}\text { Average no. of employees per } 1,000,000 \\
\text { tons } / \mathrm{km} \text { of goods transported }\end{array}$} \\
\hline Period & Paulista & Mogiana & Sorocabana & Paulista & Mogiana & Sorocabana \\
\hline 1901-1905 & 4.21 & 2.81 & 3.01 & 38.29 & 41.57 & 39.40 \\
\hline 1906-1910 & 3.69 & 2.83 & 2.69 & 22.68 & 34.90 & 32.16 \\
\hline 1911-1915 & 4.33 & 3.18 & 2.55 & 18.92 & 34.41 & 26.80 \\
\hline 1916-1920 & 4.59 & 2.69 & 3.01 & 16.12 & 27.84 & 20.57 \\
\hline
\end{tabular}

Source: Saes, As ferrovias de São Paulo, p. I 37.

schedule involved a larger number of holidays and shorter workdays followed by a decrease in wages. At the same time, the railway management began downsizing resulting from the modernization of the company's workshops. Such changes did not affect white-collar and station employees but were concentrated on trainmen, trackmen, and principally on the railway shopmen, of whom I 59 alone were dismissed between 1905 and $1906 .^{30}$

When comparing different railway companies in São Paulo it is clear that, despite the downsizing of the labour force, the ratio of employees to track length of the CPEF remained higher than that for both the Mogiana and Sorocabana railways. At the same time, its ratio of employees to goods carried was lower, showing that it was the most efficient goods carrier among the railways in São Paulo state. ${ }^{3 \mathrm{I}}$ Efficiency, however, translated into high pressure on the work-floor level. A month before the beginning of the strike the workers' press published a series of grievances against the workshop chief, Francisco Paes Leme de Monlevade, who imposed thirteen- to sixteen-hour workdays on the company's staff:

As if it were not enough working thirteen to sixteen hours a day: every week the workers must work overtime until the end of the working journey, which often finishes at midnight. Sometimes the sentinels become wet and are not allowed to change their clothes. Those who arrive five or more minutes late have a half workday taken off their wages. The employee who is caught talking with either a co-worker or someone else, is seen smoking, or is not at his workplace, even if owing to force majeure, will be punished.

Only one person at a time is allowed to go to the bathroom, and he must ask for permission and explain his reasons. No employee is allowed to take leave for business or illness while another employee is off. The despot who establishes this, and who is very religious, has always done the same wherever he has gone,

30. Leme, “Hoje há ensaio”, pp. 53-54.

3I. On the CPEF's efficiency and profitability, see Guilherme Grandi, Estado e capital ferroviário em São Paulo: a Companhia Paulista de Estradas de Ferro entre 1930 e 196I (São Paulo, 2013). 
satisfied with his well-being (will it be permanent?) and indifferent to the pain that he causes, with his vexations and his fines.

How can an employee who receives Rs $4 \$ 000$ per day [...] or who receives Rs $3 \$ 000$ or $2 \$ 600$ afford to pay his debts? Is this a wage that a worker can live on, even unpleasantly, without accumulating plenty of debts? This, when food is more and more expensive, when prices are going up while wages are going down! ${ }^{32}$

It is evident that among the railway workers' claims the wage question held a prominent place, even though the event that led to the strike was a non-economic matter. The Jundiai Worker League, which at that time acted like a real railway union, was responsible for recording all worker indictments. This League sent a set of complaints to several newspapers in São Paulo, in which workers accused station and workshop chiefs of disrespect and abuse of authority. Other problems were linked to the downsizing of the workforce, low wages, suspension of promotions, overwork, and the constant threat of dismissal and fines. ${ }^{33}$

Although there was a long list of grievances, the episode that caused the outbreak of the strike was a misunderstanding between the station chief of Jundiai-Paulista - João Gonçalves Dias - and Thomas Degani, the checker in the same station who had worked at the CPEF for eight years. According to Leme, the checker had twice requested permission from the station chief to visit his family in Itatiba, and only after a third application and following the intervention of the traffic chief and the general inspector of the railway was he granted three days' leave. Nonetheless, when he returned to work he found that he had been posted by Dias to another city, Ribeirão Bonito. Degani was disappointed with so arbitrary a measure because he had begun constructing a house in Jundiai and his family was completely dependent on him for their livelihood. ${ }^{34}$ So began the conflict, and what had originally been an internal corporate disagreement became the largest industrial labour conflict in São Paulo up to that time.

São Paulo's great railway strike of 1906 started on the morning of is May when 3,500 CPEF employees stopped work. Services were affected on I,057 kilometres of track, which carried slightly more than 80 per cent of São Paulo's coffee freight. ${ }^{35}$ At the time, the company's rail network connected important coffee districts such as Campinas, Limeira, Araras, Porto Ferreira, Rio Claro, São Carlos, Jaboticabal, and Jaú, to name but a few. The day before the strike, the railway workers had sent a letter to the Comércio de São Paulo and Il Secolo newspapers explaining the reasons for

32. A Terra Livre, I2 April 1906. All translations are mine.

33. Comércio de São Paulo, I9 May 1906.

34. Leme, “Hoje há ensaio", p. 67.

35. Gazeta de Piracicaba, I6 May 1906. 
it. ${ }^{36}$ Concerning the conflict involving Degani and Dias, the Jundiai Worker League sent two documents to the CPEF's general inspector, the engineer Manuel Pinto de Torres Neves, in which they explained the Degani case and its injustices. In these documents, the League emphasized the checker's personal qualities and demanded his immediate return to Jundiai. Moreover, they denounced the arbitrariness, pressures, and abuses suffered by workers at the hands of Dias and called for his dismissal. Between 24 April, when the first document signed by almost 400 railway workers was issued, and 2 May, when the second was sent to the general inspector, the company had still not acknowledged the workers' complaints. In the second letter, the League board observed that:

Given the staunch attitude and the general outrage of the employees in the face of the continuous threats and insults uttered by the Jundiai-Paulista station's chief against his underlings, attacking with degrading words a company of which he is unworthy to be part due to his immorality and rudeness, we are forced to ask you to find a solution by Saturday; this worthy corporation of honest workers can no longer be a victim of this ruthless head who does not even deserve to be an employee of an important railway company like Paulista. ${ }^{37}$

In the documents, the railway workers also complained about the fact that work was no longer being done according to the official assignments and, therefore, they had been obliged to assist with or complete jobs unrelated to the activity for which they had been employed. That they were overloaded with tasks was clearly due to the policy of downsizing. They also commented that there was a lowering of wages in relation to the previous period (a period when employment was still guaranteed). Finally, they highlighted the workers' discontent with the traffic chief, Francisco de Monlevade, and the station chief of Jundiai, Henrique Burnier, who were known to be "authoritarian" and "mean". ${ }^{8}$ Further, there was another longstanding worker grievance related to the Paulista Benevolent Society, which, according to the workers, hired Monlevade's relatives, who refused the workers their rights of representation and voting in the Society.

After stopping work the strikers' first act was to hand out pamphlets calling on their co-workers to attend a meeting at 8.00 a.m. on Is May in the São Jose theatre at Jundiai. The gathering was presided over by the League's lawyer, Arthur Guimarães, who addressed a large group of workers, asking them to remain peacefully in their homes and unwavering

36. Leme, “Hoje há ensaio”, pp. 62, 66.

37. Liga Operaria de Jundiahy, Documento enviado ao inspector geral da Companhia Paulista de Vias Férreas e Fluviais (Jundiaí, I906), dated 2 May 1906.

38. Comércio de São Paulo, ig May 1906. 
in the face of company pressure to re-establish the railway service. After that, other members of the League's board gave speeches. For example, Manuel Pisani detailed the reasons for the strike and mentioned that the worker leagues of Campinas and Rio Claro, as well as the Worker Federation of São Paulo (WFSP) had, through its spokesman Edgard Leuenroth, declared firm support for the strike. He reminded the CPEF workers that they were not demanding an increase in wages or a reduction in hours of work. They were simply asking for recognition, respect, and principled bosses. ${ }^{39}$

The CPEF's president-director (Antonio Prado), who was also the mayor of São Paulo city at that time, learned about the strike through the Comércio de São Paulo newspaper. In the early morning of is May, Prado was interviewed by reporters of this newspaper, to whom he said that the strike was unfair and illegal, since the workers' complaints had never been brought to his attention. The only claim he acknowledged having heard of was about the Benevolent Society. ${ }^{4}$

In addition to the other grievances mentioned, the railway workers also found that their skills and experience, which had been their ticket to remaining employed, were not honoured as railway companies promoted their own men from within. While the senior positions and skilled workers, such as engineers, had opportunities for advancement and eventually membership of the company's board of directors, the majority of unskilled workers saw similar advancement as being out of reach. Indeed, job mobility for unskilled workers was strictly limited, since the railway managers treated them as subordinates affiliated to a paternalistic enterprise, as if they were (underage) members of a corporate family. In that context, the basic wage for linemen rose from 2 to only 3 milréis a day between 1875 and I9I0, a period during which the devaluation of the Brazilian currency and inflation were significant. ${ }^{4 \mathrm{I}}$

\section{WORKING-CLASS SOLIDARITY AND STRIKE OUTCOMES}

At 8.30 a.m. the following day, the railway workers held another meeting in the same theatre, but this time it was chaired by Pisani and was attended by the Police Lieutenant Augusto Pereira Leite, who had been invited by the workers. Pisani warned his colleagues of the lies that some newspapers had been publishing about the strike and took the opportunity to read telegrams in support of the workers that had been

39. Liga Operaria de Jundiahy, Acta da assembléa geral extraordinaria realizada no recinto do Theatro S. José no dia Is de Maio de 1906 (Jundiaí, I906), dated is May 1906.

40. Comércio de São Paulo, I6 May 1906.

4I. Robert H. Mattoon, "Railroads, Coffee, and the Growth of Big Business in São Paulo, Brazil”, Hispanic American Historical Review, 57 (1977), pp. 273-295, 292. 
Table 4. Strikes in support of CPEF workers (May 1906)

\begin{tabular}{llcc}
\hline Enterprise or category & City & Beginning & Ending \\
\hline Arens Workshops (weaving) & Jundiai & Day 15 & - \\
Globo Shoes Factory & São Paulo & Day 15 & - \\
Campineiro Tannery & Campinas & Day 16 & Day 18 \\
Coachmen and wagoners & Jundiai & Day 18 & Day 19 \\
Restaurant and hotel employees & Jundiai & Day 18 & - \\
Mac Hardy (machines) & Campinas & Day 19 & Day 25 \\
Lidgerwood (machines) & Campinas & Day 19 & Day 25 \\
Ramal Férreo Campineiro (railway) & Campinas & Day 19 & Day 25 \\
Funilense (railway) & Campinas & Day 19 & Day 25 \\
Companhia Mogiana de Estradas de Ferro & Campinas & Day 19 & Day 25 \\
Alexandre Sien Mechanical Workshop & Campinas & Day 19 & - \\
Construction workers & Campinas & Day 19 & - \\
Printers' Union & Campinas & Day 19 & Day 25 \\
Faber \& Irmao & Campinas & Day 19 & Day 25 \\
Pedro Anderson & Campinas & Day 19 & Day 25 \\
Rio Claro Beer Factory & Rio Claro & Day 19 & - \\
Wagoners & Santos & Day 19 & - \\
Coachmen and tramway conductors & Campinas & Day 20 & Day 23 \\
(Campineiro Tramway) & & & \\
[600 workers of different occupation] & Dois Corregos & Day 22 & - \\
Carioca Textile Factory & Rio de Janeiro & Day 24 & - \\
Carioca Tramway & Rio de Janeiro & Day 24 & - \\
\hline
\end{tabular}

Source and notes: Leme, “Hoje há ensaio”, p. I38. In the case of ten strikes, there are no data available to indicate when they ended.

sent by several labour organizations, including the Workers' Union of Rio de Janeiro. He also said that the milliners and barbers of São Paulo city, as well as the majority of workers and merchants in Jundiai, Campinas, and Rio Claro, had declared their enthusiastic support for the strike. In fact, there were many other categories of worker who went on strike in solidarity with the CPEF's railway workers. Table 4 summarizes these enterprises and occupational categories.

The data from Table 4 illustrate two noticeable features of these strike activities. First, the relatively short duration of the walkouts, approximately five days on average, and second, the peak of the strike movement on I9 May, when the majority of organizations listed on the chart organized their stoppages. Fausto contends that the labour movement achieved its highest level of militancy on I9 May precisely when workers from important companies in Campinas city, such as Mac Hardy, Lidgerwood, and the Companhia Mogiana de Estradas de Ferro joined the strike. ${ }^{42}$ Nevertheless, 
the strike movement did not reach the São Paulo Railway Company another railway company of critical importance as it serviced the link between port of Santos and the city of São Paulo. Facing the threat that strike action might extend to port workers, the President of São Paulo state, Jorge Tibiriça, called for federal intervention. In the meantime, the WFSP supported the worker leagues by sending representatives to the main industrial cities of the state. Another typical action on the part of the WFSP and the local worker leagues during the strike was the distribution of pamphlets to encourage worker solidarity in other trades and industries. Below is an extract from one such pamphlet, written by the Jundiai Worker League and published in the Comércio de São Paulo newspaper:

\section{WORKER LEAGUE}

Comrades! As you know, our friends from the Companhia Paulista are striking against the despotism and arrogance of the three bosses from that powerful railway company and the constant persecution and extortion of the workers by those lords for their own benefit and that of their protégés. [...] So, the Companhia Paulista's board of directors, which seems to be putting stingy caprices before the company's interests, and whose management has been severely damaged, has just declared peremptorily that it will not make any concession to the strikers. [...] It is necessary that the workers do not lose, because this would involve an attack on their legitimate rights and therefore the total discrediting of our honourable class. We invite you, comrades, to strike tomorrow to increase our moral force. Go ahead, because we hope you will support our comrades from Paulista until we win. Victory is certain, and if necessary we will go on a GENERAL STRIKE. ${ }^{43}$

These views clearly suggest that militancy was increasing in São Paulo by 19 May. Not only had the working class demonstrated its support for the railway workers, in Rio Claro city the businessman Julio Stern distributed several newsletters in his own beer factory calling for solidarity with CPEF employees. Leme mentions a large number of organizations that declared their support for the railway workers. ${ }^{44}$ These organizations ranged from worker leagues to left-wing parties, law students, labour unions, religious groups, and a few business associations. In general, the level of commitment was significant if we consider the novelty of this movement at the beginning of the twentieth century. There were rumours that even the Worker League of Buenos Aires in Argentina had sent financial aid to the Jundiai Worker League. ${ }^{45}$ In São Carlos, a powerful São Paulo coffee district, there was discontent on the part of settlers, demonstrating that the movement had reached the agricultural sector, the heartbeat of the Brazilian economy. 
The outcome of the strike might have been better for the strikers if the São Paulo Railway Company workers had supported the CPEF railway strike's cause. If they had endorsed the strike, the whole export-import transport system of São Paulo would have collapsed and the labour conflict within the CPEF would have damaged the heart of the Brazilian economy: the coffee business. The WFSP regretted the behaviour of São Paulo Railway workers, whose collaboration in the transport of troops was seen by the militants as a betrayal of the working class. Some newspapers published the WFSP's bulletin, which urged the railwaymen to join the strike, for that would ensure the victory of the movement in only a few hours. The WFSP mentioned that, four days after the outbreak of the strike, the Mogiana workers, too, marched in solidarity with their CPEF co-workers. The request said: "Let's make the large artery, that gives life to the whole trade of the state, inactive and the victory of workers will be certain and immediate." 46

According to Maram, the backing by the police reinforced the owners' power, which was key to circumventing the resistance of the workers. ${ }^{47}$ In any case all emerging labour movements in Brazil encountered the vociferous bitterness of employers, encouraged by the forces of government. Thus, the CPEF strike movement began to weaken after one week of stoppages, and on 29 May 1906 a tragic episode occurred in Jundiai city. The meeting, which attracted approximately roo strikers near the main square of the city (Largo da Matriz), and the purpose of which was to decide what should be done, escalated into violence. As police on horseback approached the group of workers, shots were fired and two strikers, Ernesto Gould and Manoel Dias, were killed, as were a mounted policeman and a soldier named Pedro Evangelista de Araújo. ${ }^{48}$ Subsequently, many strikers were imprisoned and the worker mobilization lost the impetus it needed to maintain the already fading railway strike, largely because employees went back to work at the Mogiana railway on 25 May. The efforts of the WFSP to continue to resist failed at the end of May. The strike came to an end as the threats of dismissal became stronger and more frequent. There is no doubt that by the time the strike committee was no longer able to negotiate, the CPEF's board of directors knew that the strike would end in a couple of days. At the end of May, the labour press admitted that: "Anyway, the strike itself does not exist anymore. The backward and unjustified attitude of some workers of our industrial establishments let the number of supporters of a general strike appear too small in the eyes of its proponents." ${ }^{49}$

46. Il Secolo, 20 May 1906.

47. Maram, "Labor and the Left in Brazil", p. 257.

48. Delegacia de Polícia de Jundiahy, Inquérito sobre a greve na Companbia Paulista (Jundiaí, 1906), dated 29 May 1906.

49. A Platéia, 29 May 1906. 
Even if the consequences of the railway strike were not overly positive at the time due to its relatively short duration and the violent manner in which it was suppressed, I strongly believe that effects, both immediate and long-term, should not be underestimated. For instance, the strike's impact on the trade and economy of São Paulo state as a whole was profound. The roads to Jundiai and the west of the state were overcrowded by the standards of the time. The costs of transport using trolleys and riders rose substantially. The cost of renting a horse increased to roo milreis. ${ }^{50}$ In addition, it is estimated that the CPEF required at least additional 160 workers, principally firemen and conductors, to properly re-establish its railway services, since they were the sectors that remained on strike for the longest time. ${ }^{\text {I }}$ Much more important, however, were the impulses the strike gave to the further development of the managementlabour relations in general and in the railway sector in particular. Even if the railway strike did not settle all of the CPEF workers' claims, it is important to point out that in 1907, the year after the strike, Brazil legally recognized industrial and commercial employee organizations as well as of those of professional people. Furthermore, as had occurred at the Companhia Mogiana, the eight-hour day was established as the pattern of railway work by the CPEF, a clear-cut consequence of the railway strike of 1906.

\section{CONCLUSION}

The railway strike of 1906 had significant results - results that have not been fully acknowledged by all previous historiographical assessments. One ensuing development was the regulation of an eight-hour day. Important as this was, it would be too narrow to limit the consequences to this alone and to ignore the further cascade effects that arose from the strike. One of these was a significant upturn for the labour movement in the years to come. Wolfe has thus admitted that the CPEF labour dispute encouraged the organization of other workers and led the labour leadership to misjudge the political potential of workers' protests. ${ }^{52}$ Further, Maram notes that labour organizations enjoyed rapid growth from I906 to 1908, and by 1913 the movement had achieved its highest membership approximately $60,000 .{ }^{53} \mathrm{It}$ is, in any case, important to stress much more explicitly that this railway strike had a pioneering character in São Paulo's labour history because it was responsible for inaugurating a period of great social unrest involving a large number of urban workers in São Paulo state.

50. Leme, “Hoje há ensaio”, p. 8I.

s. Ibid., p. I 50 .

52. Wolfe, "Anarchist Ideology, Worker Practice”, p. 819, n. 36.

53. Maram, "Labor and the Left in Brazil", pp. $255-256$. 
As I have sought to show, the railway strike of 1906 implied a growing identity among varying categories of workers and, as a consequence, there was a re-evaluation of the railway companies' labour rules. Stoppages began in the city of Jundiai and spread quickly throughout the CPEF's line and then affected other trades and industries. The strike movement started by company employees mobilized other workers in factories making textiles, matches, cereals, hats, and shoes. Picket lines were set up and there were protests in support of the railway workers. While the organization of the strike was unsophisticated, the strikers' demands were comprehensive: regular hours, better pay, and improved working conditions. ${ }^{54}$ In fact, the conflict that gave rise to the strike was related both to maintaining employment and wage levels, and to existing measures that were constraining the autonomy of the railway labour movement.

Apart from the mobilizing effect of the strike among railway workers, it was also shown that many workers from other manufacturing sectors endorsed the CPEF railway strike, which suggests that it played a pivotal role in the process of organizing and raising awareness among São Paulo workers at the beginning of the twentieth century. Also, it was the first time that São Paulo's working class reached a high degree of militancy, demanding fundamental rights and better working conditions. In its context, the railway strike of 1906 undoubtedly provided an effective incentive to the associative spirit among many groups of urban workers. On the whole, the first great railway strike in São Paulo contributed considerably to workers' engagement in their struggles for better working conditions and basic social entitlements. Certainly, it stood as a valuable lesson for the whole of Brazilian industrial relations in the twentieth century. 